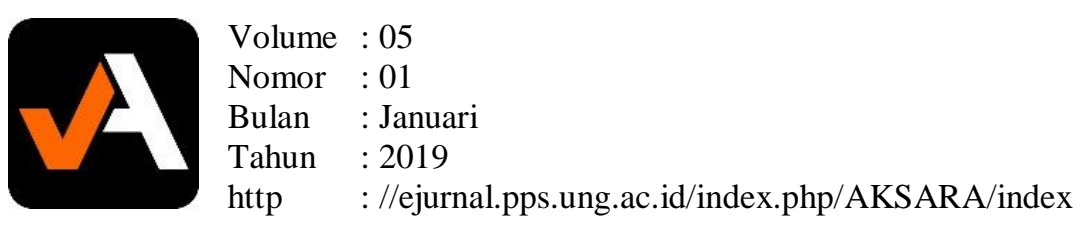

\title{
MENINGKATKAN KEMAMPUAN PENALARAN DAN DISPOSISI MATEMATIS SISWA PADA MATERI LIMIT FUNGSI DENGAN MENGGUNAKAN STRATEGI THINK-TALK-WRITE
}

\author{
Fatma Abdurahman \\ SMA Negeri 1 Gorontalo \\ fatma@gmail.com
}

Received: 25 November 2018; Revised: 1 Desember 2018; Accepted: 5 Desember 2018

\begin{abstract}
ABSTRAK
Penelitian ini bertujuan untuk: (a) mendeskripsikan proses pembelajaran menggunakan strategi Think-Talk-Write (TTW) dalam meningkatkan kemampuan penalaran dan disposisi matematis siswa pada materi limit fungsi aljabar dan (b) mengetahui kemampuan penalaran dan disposisi matematis melalui strategi TTW. Subjek penelitian ini adalah siswa kelas XI IPA1 SMA Negeri 1 Gorontalo berjumlah 30 orang. Desain penelitian menggunakan prosedur tindakan Model Kemmis dan McTaggart, yaitu: perencanaan, pelaksanaan, observasi dan refleksi. Instrumen penelitian menggunakan tes untuk menilai kemampuan penalaran dan lembar pengamatan menilai disposisi matematis siswa. Temuan penelitian membuktikan bahwa kemampuan penalaran dan disposisi matematis siswa pada materi limit fungsi aljabar dapat meningkat melalui strategi TTW. Pada Siklus I sebanyak $16(53,33 \%)$ orang mencapai nilai 60 dan kemudian meningkat menjadi $20(66,67 \%)$ orang pada Siklus II, dan meningkat lagi menjadi 27 (90\%) orang pada Siklus III. Sedangkan disposisi matematis siswa pada Siklus I sebesar 76,12\%, meningkat menjadi 80,27\% pada Siklus II, serta menjadi 90,03\% pada Siklus III.
\end{abstract}

Kata-Kata Kunci: penalaran, disposisi matematis, strategi TTW.

\section{PENDAHULUAN}

Mata pelajaran matematika di SMA bertujuan agar siswa memiliki berbagai kemampuan, diantaranya penalaran dan disposisi matematis. Kemampuan penalaran memiliki peran penting dalam melatih dan mengembangkan proses berpikir sebab kemampuan ini merupakan pondasi bagi siswa dalam belajar matematika. Jika siswa mampu bernalar dengan baik, maka ia tidak akan mengalami kesulitan dalam menghubungkan benda nyata dan gambar, memahami soal-soal cerita ke dalam ide matematika, serta menjelaskan ide matematika tersebut dengan tepat, baik lisan maupun tulisan. Sebaliknya, bagi siswa memiliki nalar yang kurang baik, maka ia cenderung mengikuti aktivitas pembelajaran dengan apa adanya, tanpa mengetahui maknanya dan hanya menyalin apa yang disampaikan guru. Dengan kata lain, penalaran sangat diperlukan siswa dalam meningkatkan hasil belajar matematika.

Kenyataan yang seringkali dijumpai pada pembelajaran matematika, yaitu sebagian besar siswa mengalami kesulitan dalam memahami soal-soal penalaran. Hasil analisis terhadap data pra penelitian di kelas XI IPA.1 menunjukan bahwa faktor 


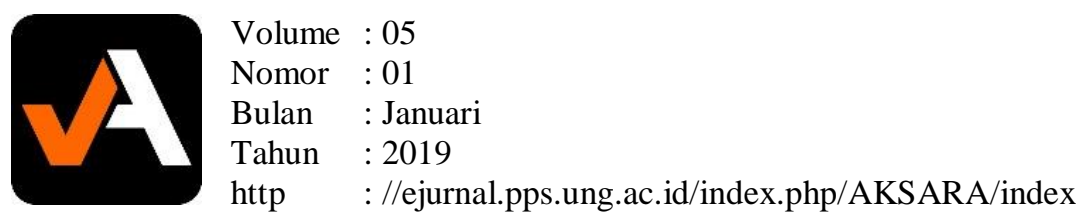

penyebabnya adalah cara-cara siswa mengerjakan soal-soal penalaran kurang tepat. Materi limit fungsi aljabar perlu dikuasai oleh siswa sebab merupakan prasyarat untuk menguasai materi selanjutnya, seperti turunan fungsi dan integral. Selain itu, siswa hanya mengikuti pelajaran dan mencatat penyelesaian soal yang dijelaskan guru. Jika diberikan tugas atau soal, jawaban siswa cenderung bersifat imitatif. Mereka hanya menyalin jawaban kelompoknya tanpa dibarengi dengan pemahaman yang baik.

Agar proses pembelajaran memberi dampak positif bagi siswa, maka guru sebaiknya memilih strategi pembelajaran yang tepat. Pemilihan strategi pembelajaran yang tepat dapat mempengaruhi kemampuan penalaran dan disposisi matematis siswa terhadap materi yang diajarkan. Salah satu strategi yang dapat digunakan adalah Think-Talk-Write (TTW). Strategi TTW termasuk pada tipe pembelajaran kooperatif yang implementasinya terdiri dari tiga tahapan: think, talk, dan write. Penggunaan strategi TTW pada penelitian ini dititikberatkan pada masalah rendahnya kemampuan penalaran dan disposisi matematis dengan fokus materi pada limit fungsi aljabar. Kemampuan penalaran dibatasi pada lima indikator, yaitu: (1) penyusunan pembuktian langsung, (2) manipulasi matematika, (3) penarikan kesimpulan atau bukti, serta pemberian alasan terhadap kesimpulan atau bukti tersebut, (4) pemeriksaan kesahihan suatu argumen dan (5) penentuan pola atau gejala matematis. Sementara disposisi matematis dibatasi pada lima aspek, yaitu: (1) rasa ingin tahu, (2) perhatian, (3) minat, (4) ulet dan (5) percaya diri.

\section{TINJAUAN PUSTAKA}

\section{Hakikat Kemampuan Penalaran}

Dalam konteks pengajaran matematika di SMA, salah satu prestasi siswa dapat diukur melalui kemampuan penalaran. Penalaran merupakan suatu proses berpikir dalam menarik suatu kesimpulan dan ditandai oleh beberapa ciri, yaitu: (a) adanya suatu pola berpikir yang secara luas dan logis dan (b) bersifat analitik dari proses berpikir yang didasarkan pada langkah-langkah tertentu (Suariasumantri, 1999: 4243). Ada tujuh indikator penalaran, yaitu: (a) menyajikan pernyataan matematika secara lisan, tertulis, gambar dan diagram, (b) mengajukan pendugaan, (c) melakukan manipulasi matematika, (d) menarik kesimpulan, menyusun bukti, memberikan alasan atau bukti terhadap solusi, (e) menarik kesimpulan dari pernyataan, (f) memeriksa kesahihan suatu argumen serta $(\mathrm{g})$ menentukan pola atau sifat dari gejala matematis untuk membuat generalisasi (Depdiknas, 2006: 14).

\section{Hakikat Disposisi Matematis}

Mulyana (2009: 19) mengartikan disposisi matematis merupakan perubahaan siswa dalam memandang dan bersikap terhadap matematika serta bertindak ketika belajar matematika. Perubahan tersebut menurut Maxwell (2001:4) nampak pada: (a) kecenderungan, yaitu sikap siswa dalam belajar, (b) kepekaan, yaitu kesiapan siswa dalam belajar, (c) kemampuan, yaitu fokus atau perhatian siswa selama proses pembelajaran dari awal sampai akhir dan (d) kesenangan, yaitu perasaan siswa selama proses pembelajaran. Komponen disposisi matematis menurut Kurikulum Matematika SMA berkaitan dengan berbagai sikap, yaitu memiliki rasa ingin tahu, 


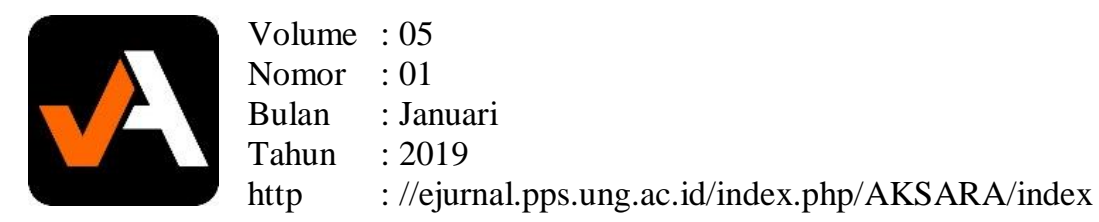

perhatian dan minat dalam mempelajari matematika, serta sikap ulet dan percaya diri dalam pemecahan masalah (Depdiknas, 2006: 346).

\section{Materi Limit Fungsi Aljabar}

Materi limit fungsi aljabar untuk indikator kemampuan penalaran adalah sebagai berikut.

(a) Menyusun pembuktian langsung, yaitu kemampuan membuktikan kebenaran dari suatu pernyataan. Contoh soal: Melalui pembagian pembilang dan penyebut dengan variabel $x$ yang mempunyai pangkat tertinggi, diperoleh: $\lim _{x \rightarrow \infty} \sqrt{\frac{2 x^{2}-3 x}{8 x^{2}+5}}=$ $\lim _{x \rightarrow \infty} \sqrt{\frac{\frac{2 x^{2}-3 x}{x^{2}}}{\frac{8 x^{2}+5}{x^{2}}}}=\frac{1}{2}$

(b) Melakukan manipulasi matematika, yaitu kemampuan menyelesaikan suatu permasalahan dengan cara atau teorama. Melalui penggunaan teorema limit, soal $\lim _{x \rightarrow} \frac{x \cdot\left(x^{2}-1\right)}{3 x+2}$ dapat diselesaikan: $\lim _{x \rightarrow 3} \frac{x \cdot\left(x^{2}-1\right)}{3 x+2}=\frac{\left\{\lim _{x \rightarrow 3} x\right\} \cdot\left\{\lim _{x \rightarrow 3}\left(x^{2}-1\right)\right\}}{\lim _{x \rightarrow 3}(3 x+2)}=\frac{3 \cdot\left(3^{2}-1\right)}{3 \cdot 3+2}$ $=2 \frac{2}{11}$

\begin{tabular}{|l|l|l|l|l|l|l|l|l|l|}
\hline $\mathrm{X}$ & 2,9 & 2,99 & 2,999 & 2,9999 & $\rightarrow 3 \leftarrow$ & 3,0001 & 3,001 & 3,01 & 3,1 \\
\hline $\mathrm{f}(\mathrm{x})$ & 5,9 & 5,99 & 5,999 & 5,9999 & $?$ & 6,0001 & 6,001 & 6,01 & 6,1 \\
\hline
\end{tabular}

\section{METODE PENELITIAN}

Penelitian ini dilaksanakan di SMA Negeri 1 Gorontalo pada semester genap tahun pelajaran 2013/2014 selama enam bulan, yaitu dari minggu ke-III bulan Maret s.d. minggu ke-IV bulan Juni tahun 2014. Subyek penelitian ini adalah siswa kelas XI IPA.1 yang berjumlah 30 orang dengan karakteristik yang bervariasi. Analisis data kemampuan penalaran siswa menggunakan rentang skor 0 s.d 10. Klasifikasi nilai menggunakan 5 kriteria, yaitu: sangat kurang (nilai $\leq 50$ ); kurang (50 s.d. 59); cukup (60 s.d. 79); baik (80 s.d. 89); dan sangat baik (90 s.d 100). Analisis data disposisi matematis siswa, kegiatan guru dan siswa menggunakan skala Likert 1 s.d 4. Jumlah skor pada kriteria kurang dikalikan 1, kriteria cukup dikalikan 2, kriteria baik dikalikan 3, dan kriteria sangat baik dikalikan 4. Klasifikasi skor menggunakan 4 kriteria, yaitu: kurang (nilai $\leq 60$ ); cukup (60 s.d. 79); baik (80 s.d. 89); dan sangat baik (90 s.d 100).

\section{HASIL PENELITIAN DAN PEMBAHASAN}

\section{Siklus I.}

Hasil observasi kegiatan guru ditampilkan pada tabel 1 berikut ini.

Tabel 1

Hasil Observasi Kegiatan Guru pada Siklus I 


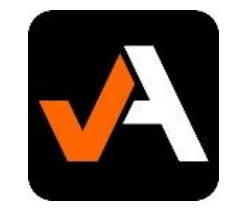

Volume : 05

Nomor : 01

Bulan : Januari

Tahun : 2019

http : //ejurnal.pps.ung.ac.id/index.php/AKSARA/index

\begin{tabular}{|c|c|c|c|c|c|c|c|}
\hline \multirow[b]{2}{*}{ No } & \multirow{2}{*}{$\begin{array}{l}\text { Tahapan } \\
\text { Kegiatan } \\
\text { Guru }\end{array}$} & \multicolumn{4}{|l|}{ Kriteria } & \multirow{2}{*}{$\begin{array}{l}\text { Jumlah } \\
\text { Skor }\end{array}$} & \multirow[b]{2}{*}{$\%$} \\
\hline & & Kurang & Cukup & Baik & $\begin{array}{l}\text { Sangat } \\
\text { Baik }\end{array}$ & & \\
\hline 1. & $\begin{array}{l}\text { Kegiatan } \\
\text { Awal }\end{array}$ & 0 & 0 & 3 & 8 & 11 & 22,45 \\
\hline 2. & Kegiatan Inti & 2 & 12 & 6 & 12 & 32 & 65,31 \\
\hline 3. & $\begin{array}{l}\text { Kegiatan } \\
\text { Akhir }\end{array}$ & 0 & 2 & 0 & 4 & 6 & 12,24 \\
\hline \multicolumn{2}{|c|}{ Jumlah Skor } & 2 & 14 & 9 & 24 & 49 & 100 \\
\hline \multicolumn{2}{|c|}{$\begin{array}{ll}\text { Jumlah } & \text { Skor } \\
\text { Hitung } & \end{array}$} & 2 & 28 & 27 & 96 & 153 & \\
\hline
\end{tabular}

Berdasarkan tampilan data di atas, masih terdapat $19,61 \%$ aspek observasi yang masih belum optimal, sedangkan 80,39 sudah optimal.

Hasil observasi terhadap kegiatan siswa pada siklus I adalah sebagai berikut.

Tabel 2

Hasil Observasi terhadap Kegiatan Siswa pada Siklus I

\begin{tabular}{|c|c|c|c|c|c|c|c|c|}
\hline \multirow[b]{2}{*}{ No } & \multirow[b]{2}{*}{ Aspek Observasi Kegiatan Siswa } & \multicolumn{4}{|c|}{ Kriteria } & \multirow{2}{*}{\multicolumn{2}{|c|}{$\begin{array}{l}\text { Jumla Rata- } \\
\text { h Skor Rata }\end{array}$}} & \multirow[b]{2}{*}{$\%$} \\
\hline & & $\begin{array}{l}\text { Kuran } \\
\text { g }\end{array}$ & Cukup & $\begin{array}{l}\text { Bai } \\
\mathrm{k}\end{array}$ & $\begin{array}{l}\text { Sangat } \\
\text { Baik }\end{array}$ & & & \\
\hline 1. & $\begin{array}{l}\text { Mendengarkan/memperhatikan } \\
\text { penjelasan guru. }\end{array}$ & 8 & 20 & 21 & 20 & 69 & $\begin{array}{l}2,3 \\
0\end{array}$ & 57,5 \\
\hline 2. & Membaca dan memahami LKS. & 10 & 8 & 30 & 24 & 72 & $\begin{array}{l}2,4 \\
0\end{array}$ & 60 \\
\hline 3. & jakan latihan pada LKS. & 1 & 36 & 24 & 12 & 73 & $\begin{array}{l}2,4 \\
3\end{array}$ & 60,8 \\
\hline 4. & $\begin{array}{l}\text { Berdisksi/bertanya antarsiswa } \\
\text { dan guru. }\end{array}$ & 6 & 30 & 18 & 12 & 66 & $\begin{array}{l}2,2 \\
0\end{array}$ & 55 \\
\hline 5. & Perilaku lainnya yang relevan. & 8 & 32 & 18 & 0 & 58 & $\begin{array}{l}1,9 \\
3\end{array}$ & 48,3 \\
\hline Jum & lah Skor & 33 & 126 & 111 & 68 & 338 & & \\
\hline
\end{tabular}

Tabel di atas menunjukan bahwa jumlah skor untuk kriteria kurang adalah 33 atau 9,8\%, kriteria cukup sebanyak 126 atau 37,28\%, kriteria baik sebanyak 111 atau $32,84 \%$ dan kriteria sangat baik sebanyak 68 atau 20,1\%.

Sehubungan dengan pemberian evaluasi ditemukan hasil kemampuan penalaran siswa pada Siklus I terlihat pada tabel 3 berikut ini.

Tabel 3

Kemampuan Penalaran Siswa pada Siklus I 


\begin{tabular}{|l|l|l|l|l|}
\hline No & Rentang Nilai & Kriteria & Frekuensi & $\%$ \\
\hline 1. & $0-49$ & Sangat Kurang & 2 & 6,67 \\
\hline 2. & $50-59$ & Kurang & 12 & 40 \\
\hline 3. & $60-79$ & Cukup & 14 & 46,67 \\
\hline 4. & $80-89$ & Baik & 2 & 6,67 \\
\hline 5. & $90-100$ & Sangat Baik & 0 & 0 \\
\hline Jumlah & 30 & 100 \\
\hline
\end{tabular}

Data di atas menunjukkan bahwa kemampuan penalaran siswa pada Siklus I kurang optimal. Hanya enambelas orang atau 53,33\% yang tuntas.

Hasil observasi terhadap disposisi matematis siswa pada Siklus I disajikan pada tabel 4 di bawah ini.

Tabel 4

Disposisi Matematis Siswa pada Siklus I

\begin{tabular}{|c|c|c|c|c|c|c|c|c|}
\hline \multirow[b]{2}{*}{ No } & \multirow[b]{2}{*}{$\begin{array}{l}\text { Aspek Disposisi } \\
\text { Matematis }\end{array}$} & \multicolumn{4}{|l|}{ Kriteria } & \multirow[b]{2}{*}{$\begin{array}{l}\text { Jumlah } \\
\text { Skor }\end{array}$} & \multirow[b]{2}{*}{$\begin{array}{l}\text { Rata- } \\
\text { Rata }\end{array}$} & \multirow[b]{2}{*}{$\%$} \\
\hline & & Kurang & Cukup & Baik & $\begin{array}{l}\text { Sangat } \\
\text { Baik }\end{array}$ & & & \\
\hline 1. & Rasa Ingin Tahu & 4 & 22 & 33 & 16 & 75 & 2,5 & 62,5 \\
\hline 2. & Perhatian & 6 & 22 & 30 & 12 & 70 & 2,33 & 58,3 \\
\hline 3. & Minat & 4 & 16 & 24 & 40 & 84 & 2,8 & 70 \\
\hline 4. & Ulet & 4 & 24 & 21 & 28 & 77 & 2,57 & 64,2 \\
\hline 5. & Percaya Diri & 3 & 34 & 21 & 12 & 70 & 2,33 & 58,3 \\
\hline \multicolumn{2}{|c|}{ Jumlah Skor } & 21 & 118 & 129 & 108 & 276 & & \\
\hline \multicolumn{2}{|c|}{ Jumlah Skor Hitung } & 21 & 236 & 387 & 432 & 1076 & & \\
\hline
\end{tabular}

Data di atas menunjukkan bahwa jumlah skor untuk kriteria kurang adalah 21 $(1,96 \%)$, kriteria cukup sebanyak $118(21,93 \%)$, kriteria baik sebanyak $129(35,97 \%)$ dan kriteria sangat baik sebanyak 108 (40,15\%).

\section{Siklus II.}

Data observasi terhadap guru seperti terlihat pada tabel di bawah ini.

\section{Tabel 5}

Hasil Observasi terhadap Guru pada Siklus II

\begin{tabular}{|c|c|c|c|c|c|c|c|}
\hline \multirow[b]{2}{*}{ No } & \multirow[b]{2}{*}{$\begin{array}{l}\text { Tahapan } \\
\text { Kegiatan Guru }\end{array}$} & \multicolumn{4}{|l|}{ Kriteria } & \multirow[b]{2}{*}{$\begin{array}{l}\text { Jumlah } \\
\text { Skor }\end{array}$} & \multirow[b]{2}{*}{$\%$} \\
\hline & & Kurang & Cukup & Baik & $\begin{array}{l}\text { Sangat } \\
\text { Baik }\end{array}$ & & \\
\hline 1. & Kegiatan Awal & 1 & 2 & 0 & 4 & 7 & 13,73 \\
\hline 2. & Kegiatan Inti & 1 & 8 & 15 & 12 & 36 & 70,59 \\
\hline 3. & $\begin{array}{l}\text { Kegiatan } \\
\text { Akhir }\end{array}$ & 0 & 0 & 0 & 8 & 8 & 15,69 \\
\hline \multicolumn{2}{|c|}{ Jumlah Skor } & 2 & 10 & 15 & 24 & 51 & 100 \\
\hline \multicolumn{2}{|c|}{ Jumlah Skor Hitung } & 2 & 20 & 45 & 96 & 163 & \\
\hline
\end{tabular}

Tabel 6 terdapat 2 masih terdapat 13,5\% aspek observasi yang masih belum optimal, sedangkan $86,5 \%$ sudah optimal. 


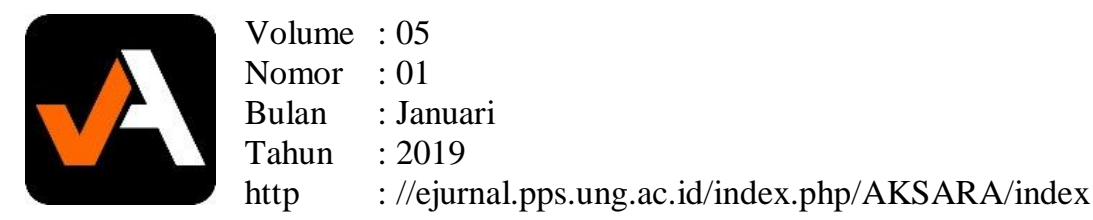

Data obervasi kegiatan siswa pada Siklus II dapat dilihat pada tabel 6.

Tabel 6

Hasil Observasi terhadap Kegiatan Siswa pada Siklus II

\begin{tabular}{|c|c|c|c|c|c|c|c|c|}
\hline \multirow[b]{2}{*}{ No } & \multirow[b]{2}{*}{ Aspek Observasi Kegiatan Siswa } & \multicolumn{4}{|c|}{ Kriteria } & \multirow[b]{2}{*}{$\begin{array}{l}\text { Jumla } \\
\text { h Skor }\end{array}$} & \multirow[b]{2}{*}{$\begin{array}{l}\text { Rata- } \\
\text { Rata }\end{array}$} & \multirow[b]{2}{*}{$\%$} \\
\hline & & $\begin{array}{l}\text { Kuran } \\
\text { g }\end{array}$ & Cukup & $\begin{array}{l}\text { Bai } \\
\mathrm{k}\end{array}$ & $\begin{array}{c}\text { Sanga } \\
\text { t Baik }\end{array}$ & & & \\
\hline 1. & $\begin{array}{l}\text { Mendengarkan/memperhatikan } \\
\text { penjelasan guru. }\end{array}$ & 0 & 14 & 48 & 28 & 90 & $\begin{array}{l}3,0 \\
0\end{array}$ & 75 \\
\hline 2. & Membaca dan memahami LKS. & 0 & 16 & 45 & 28 & 89 & $\begin{array}{l}2,9 \\
7\end{array}$ & 74,2 \\
\hline 3. & Mengerjakan latihan pada LKS. & 0 & 24 & 45 & 12 & 81 & $\begin{array}{l}2,7 \\
0\end{array}$ & 67,5 \\
\hline 4. & $\begin{array}{l}\text { Berdisksi/bertanya antarsiswa } \\
\text { dan guru. }\end{array}$ & 4 & 28 & 27 & 12 & 71 & $\begin{array}{l}2,3 \\
7\end{array}$ & 59,2 \\
\hline 5. & $\begin{array}{l}\text { Perilaku lainnya yang relevan } \\
\text { dengan kegiatan pembelajaran. }\end{array}$ & 1 & 32 & 39 & 0 & 72 & $\begin{array}{l}2,4 \\
0\end{array}$ & 60 \\
\hline \multicolumn{2}{|c|}{ Jumlah Skor } & 5 & 114 & 204 & 80 & 403 & & \\
\hline
\end{tabular}

Data di atas menampilkan skor kriteria kurang adalah 5 (1,2\%), kriteria cukup sebanyak 114 (28,29\%), kriteria baik sebanyak 204 (50,62\%) dan kriteria sangat baik sebanyak $80(19,9 \%)$.

Data evaluasi pertemuan ketiga Siklus II disajikan pada tabel berikut ini.

Tabel 7

Kemampuan Penalaran Siswa pada Siklus II

\begin{tabular}{|l|l|l|l|l|}
\hline No & Rentang Nilai & Kriteria & Frekuensi & $\%$ \\
\hline 1. & $0-49$ & Sangat Kurang & 2 & 6,67 \\
\hline 2. & $50-59$ & Kurang & 8 & 26,67 \\
\hline 3. & $60-79$ & Cukup & 16 & 53,33 \\
\hline 4. & $80-89$ & Baik & 3 & 10 \\
\hline 5. & $90-100$ & Sangat Baik & 1 & 3,33 \\
\hline \multicolumn{2}{|l}{ Jumlah } & 30 & 100 \\
\hline
\end{tabular}

Tampilan data Siklus II pada tabel di atas memberikan gambaran bahwa terdapat duapuluh siswa sudah mencapai nilai KKM atau lebih. Namun demikian, penelitian ini belum mencapai target yang diharapkan karena persentase capaian siswa yang mencapai nilai 60 atau lebih hanya sebesar 66,67\%. Dengan kata lain, masih ada sepuluh orang atau 33,33\% yang belum tuntas. Sedangkan indikator keberhasilan yang ingin dicapai adalah $85 \%$.

Sehubungan dengan hasil pengamatan terhadap disposisi matematis siswa pada pelaksanaan pembelajaran Siklus II dapat dilihat pada tabel berikut. 


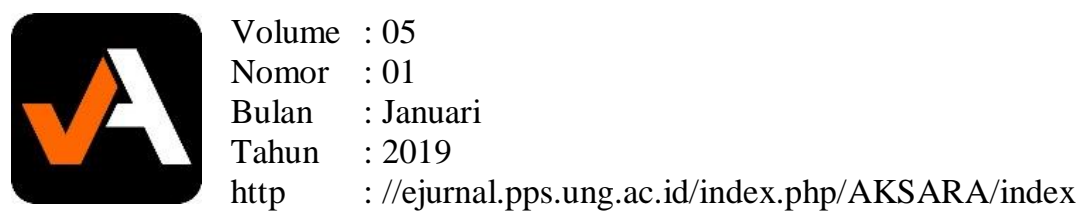

Tabel 8

Disposisi Matematis Siswa pada Siklus II

\begin{tabular}{|c|c|c|c|c|c|c|c|c|}
\hline \multirow[b]{2}{*}{ No } & \multirow{2}{*}{$\begin{array}{l}\text { Aspek } \\
\text { Disposisi } \\
\text { Matematis }\end{array}$} & \multicolumn{4}{|l|}{ Kriteria } & \multirow{2}{*}{$\begin{array}{l}\text { Jumlah } \\
\text { Skor }\end{array}$} & \multirow{2}{*}{$\begin{array}{l}\text { Rata- } \\
\text { Rata }\end{array}$} & \multirow[b]{2}{*}{$\%$} \\
\hline & & Kurang & Cukup & Baik & $\begin{array}{l}\text { Sangat } \\
\text { Baik }\end{array}$ & & & \\
\hline 1. & $\begin{array}{l}\text { Rasa Ingin } \\
\text { Tahu }\end{array}$ & 1 & 20 & 45 & 16 & 82 & 2,73 & 68,3 \\
\hline 2. & Perhatian & 1 & 24 & 39 & 16 & 80 & 2,67 & 66,7 \\
\hline 3. & Minat & 1 & 20 & 30 & 36 & 87 & 2,9 & 72,5 \\
\hline 4. & Ulet & 4 & 18 & 24 & 36 & 82 & 2,72 & 68,3 \\
\hline 5. & Percaya Diri & 3 & 30 & 30 & 8 & 71 & 2,37 & 59,2 \\
\hline \multicolumn{2}{|c|}{ Jumlah Skor } & 10 & 112 & 168 & 112 & 402 & & \\
\hline \multicolumn{2}{|c|}{$\begin{array}{ll}\text { Jumlah } & \text { Skor } \\
\text { Hitung } & \end{array}$} & 10 & 224 & 504 & 448 & 1186 & & \\
\hline
\end{tabular}

Memperhatikan data di atas, maka diperoleh jumlah skor hitung untuk kriteria kurang adalah $10(0,84 \%)$, kriteria cukup sebanyak 224 (18,89\%), kriteria baik sebanyak 504 (42,57\%) dan kriteria sangat baik sebanyak 448 (37,77\%). Berdasarkan hasil-hasil yang diperoleh di atas, maka guru mitra bersama-sama dengan peneliti kembali melakukan refleksi. Hasil refleksi adalah jumlah siswa yang tuntas belajar hanya sebesar 66,67\%. Akan tetapi, penerapan strategi TTW telah memberikan pengalaman belajar yang bermakna bagi siswa, terutama ketika mereka merumuskan satu jawaban dari berbagai pendapat yang berbeda. Sikap kooperatif siswa yang sangat tinggi dalam mengerjakan tugas kelompok sangat membantu untuk menumbuhkan disposisi matematis siswa selama pembelajaran matematika, khususnya materi limit fungsi aljabar.

\section{Siklus III.}

Berdasarkan pelaksanaan Siklus III diperoleh data observasi terhadap guru pada tabel berikut ini.

Tabel 9

Hasil Observasi terhadap Guru pada Siklus III

\begin{tabular}{|c|c|c|c|c|c|c|c|}
\hline \multirow{2}{*}{ No } & \multirow{2}{*}{$\begin{array}{l}\text { Tahapan } \\
\text { Kegiatan Guru }\end{array}$} & \multicolumn{4}{|l|}{ Kriteria } & \multirow{2}{*}{$\begin{array}{l}\text { Jumlah } \\
\text { Skor }\end{array}$} & \multirow{2}{*}{$\%$} \\
\hline & & Kurang & Cukup & Baik & Sangat Baik & & \\
\hline 1. & Kegiatan Awal & 0 & 0 & 0 & 12 & 12 & 18,46 \\
\hline 2. & Kegiatan Inti & 0 & 4 & 9 & 32 & 45 & 69,23 \\
\hline 3. & Kegiatan Akhir & 0 & 0 & 0 & 8 & 8 & 12,31 \\
\hline \multicolumn{2}{|c|}{ Jumlah Skor } & 0 & 4 & 9 & 52 & 65 & 100 \\
\hline \multicolumn{2}{|c|}{ Jumlah Skor Hitung } & 0 & 8 & 27 & 208 & 243 & \\
\hline
\end{tabular}

Data hasil observasi terhadap guru pada Siklus III menunjukkan bahwa jumlah skor hitung untuk kriteria cukup adalah 8 (3,29\%), kriteria baik adalah $27(11,11 \%)$ 
dan kriteria sangat baik adalah $208(85,6 \%)$. Berdasarkan hasil perhitungan diperoleh jumlah skor hitung untuk kriteria kurang dan cukup hanya sebanyak 8 atau 3,29\% sedangkan jumlah skor hitung untuk kriteria baik dan sangat baik sebanyak 235 atau $96,7 \%$.

Sehubungan dengan observasi terhadap kegiatan siswa pada Siklus III, diperoleh data pada sajian tabel di bawah ini.

Tabel 10

Hasil Observasi terhadap Kegiatan Siswa pada Siklus III

\begin{tabular}{|c|c|c|c|c|c|c|c|c|}
\hline \multirow[b]{2}{*}{ No } & \multirow[b]{2}{*}{ Aspek Observasi Kegiatan Siswa } & \multicolumn{4}{|c|}{ Kriteria } & \multirow[b]{2}{*}{$\begin{array}{l}\text { Jumlah } \\
\text { Skor }\end{array}$} & \multirow[b]{2}{*}{$\begin{array}{l}\text { Rata- } \\
\text { Rata }\end{array}$} & \multirow[b]{2}{*}{$\%$} \\
\hline & & $\begin{array}{l}\text { Kuran } \\
\text { g }\end{array}$ & Cukup & $\begin{array}{l}\text { Bai } \\
\mathrm{k}\end{array}$ & $\begin{array}{l}\text { Sanga } \\
\text { t Baik }\end{array}$ & & & \\
\hline 1. & $\begin{array}{l}\text { Mendengarkan/memperhatikan } \\
\text { penjelasan guru. }\end{array}$ & 0 & 0 & 45 & 60 & 105 & 3,5 & 87,5 \\
\hline 2. & Membaca dan memahami LKS. & 0 & 0 & 33 & 76 & 109 & $\begin{array}{l}3,6 \\
3\end{array}$ & 90,8 \\
\hline 3. & Mengerjakan latihan pada LKS. & 0 & 0 & 36 & 68 & 106 & $\begin{array}{l}3,5 \\
3\end{array}$ & 88,3 \\
\hline 4. & $\begin{array}{l}\text { Berdisksi/bertanya antarsiswa } \\
\text { dan guru. }\end{array}$ & 0 & 4 & 30 & 72 & 106 & $\begin{array}{l}3,5 \\
3 \\
\end{array}$ & 88,3 \\
\hline 5. & $\begin{array}{l}\text { Perilaku lainnya yang relevan } \\
\text { dengan kegiatan pembelajaran. }\end{array}$ & 0 & 4 & 33 & 68 & 105 & $\begin{array}{l}3,5 \\
0 \\
\end{array}$ & 87,5 \\
\hline \multicolumn{2}{|c|}{ Jumlah Skor } & 0 & 10 & 177 & 344 & 531 & & \\
\hline
\end{tabular}

Berdasarkan data di atas, maka dapat dikatakan bahwa jumlah skor untuk kriteria cukup sebanyak 10 (1,88\%), kriteria baik sebanyak 177 (33,33\%) dan kriteria sangat baik sebanyak $344(64,8 \%)$

Selanjutnya kemampuan penalaran siswa pada Siklus III dapat ditampilkan secara sederhana pada tabel di bawah ini.

Tabel 11

Kemampuan Penalaran Siswa pada Siklus III

\begin{tabular}{|l|l|l|l|l|}
\hline No & Rentang Nilai & Kriteria & Frekuensi & $\%$ \\
\hline 1. & $0-49$ & Sangat Kurang & 0 & 0 \\
\hline 2. & $50-59$ & Kurang & 3 & 10 \\
\hline 3. & $60-79$ & Cukup & 7 & 23,33 \\
\hline 4. & $80-89$ & Baik & 12 & 40 \\
\hline 5. & $90-100$ & Sangat Baik & 8 & 26,67 \\
\hline \multicolumn{2}{|l}{ Jumlah } & 30 & 100 \\
\hline
\end{tabular}

Berdasarkan data di atas, maka dapat dikatakan bahwa dari tigapuluh siswa sebagai subyek penelitian, terdapat duapuluh tujuh orang atau $90 \%$ telah mencapai nilai di atas 60 atau dikatakan tuntas belajar. Sementara $10 \%$ atau tiga siswa belum 


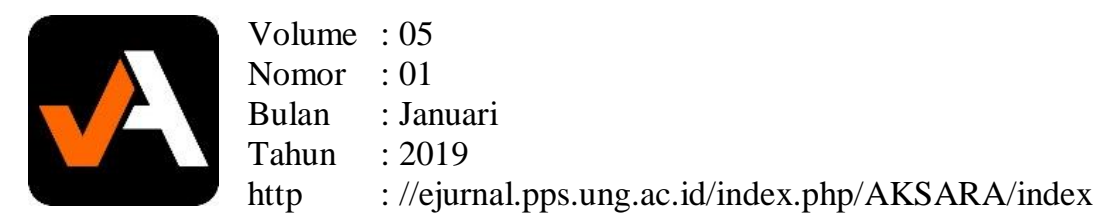

bisa mencapai ketuntasan belajar sebab nilai yang diperoleh di bawah KKM atau tndikator keberhasilan. Jika dilihat tampilan data pada tabel di atas, jelas bahwa siswa yang belum berhasil sudah berada pada rentang nilai 50 s.d. 59. Ini berarti bahwa siswa yang belum tuntas memiliki peluang besar untuk mencapai nilai KKM apabila diberikan pengayaan materi yang telah diajarkan.

\section{PENUTUP}

Berdasarkan hasil dan pembahasan penelitian, maka dapat ditarik simpulan sebagai berikut. Pertama, strategi TTW dapat meningkatkan kemampuan penalaran siswa pada materi limit fungsi aljabar, baik individu maupun kelompok. Kedua, penggunaan strategi TTW dapat meningkatkan disposisi matematis siswa pada materi limit fungsi aljabar. Penggunaan media LKS dan LCD yang dipadukan dengan kegiatan penugasan, diskusi dan presentasi kelompok, pemberian penghargaan, pemberikan koreksi langsung terhadap jawaban siswa pada diskusi kelompok, dan optimalisasi peran tutor sebaya dalam kegiatan sebaya dapat membantu disposisi matematis siswa pada materi limit fungsi aljabar. Ketiga, penggunaan strategi TTW dapat membantu siswa yang memiliki tingkat kemampuan penalaran dan disposisi matematis yang rendah pada pada materi limit fungsi aljabar. Tindakan yang dilakukan adalah melalui pengelompokan siswa secara heterogen dengan tingkat pengetahuan, minat serta motivasi yang bervariasi sehingga antara siswa yang satu dapat membantu siswa yang lainnya.

\section{DAFTAR PUSTAKA}

Departemen Pendidikan Nasional. 2006. Standar Kompetensi dan Kompetensi Dasar Mata Pelajaran Matematika. Jakarta: Depdiknas.

Gerlach, Vernon S. dan Ely, Donald P. 1980. Teaching \& Media: A Systematic Approach. New Jersey: Prentice-Hall, Inc.

Kemmis, Stephen dan McTaggart, Robbin. 1988. The Action Research Planner. Victory: Deakin University Press.

Maxwell, K. 2001. Positive Learning Dispositions in Mathematics. [Online]. www.education.auckland.ac.nz/2001/ACE_Paper_3_Issue_11.doc diakses 17 Maret 2014.

Mulyana, Endang. 2009. Pengaruh Model Pembelajaran Matematika Knisley Terhadap Peningkatan Pemahaman dan Disposisi Matematika Siswa SMA Program IPA. Disertasi UPI. Bandung. Tidak Diterbitkan.

Rusman. 2011. Model-Model Pembelajaran Mengembangkan Profesionalisme Guru. Jakarta: PT. RajaGrafindo Persada.

Suriasumatri, Jujun S. 1999. Filsafat Ilmu: Sebuah Pengantar Populer. Jakarta: Sinar Harapan. 


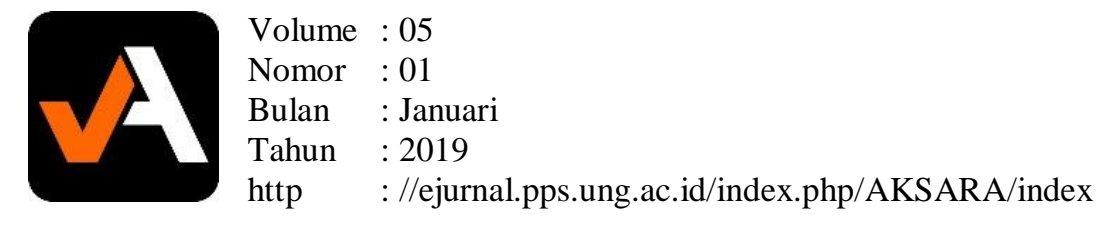

Uno, Hamzah. 2006. Orientasi Baru dalam Psikologi Pembelajaran. Jakarta: Bumi Aksara.

Winayawati, L., Waluya, S. B., dan Junaedi, I. 2012. Implementasi Model Pembelajaran Kooperatif dengan Strategi Think-Talk-Write terhadap Kemampuan Menulis Rangkuman dan Pemahaman Matematis Materi Integral dalam Unnes Journal of Research Mathematics Education. Juni 2012. Tersedia di http://journal.unnes.ac.id/sju/index.php. 